\title{
Spectrofluorimetric determination of amlodipine in human plasma without derivatization
}

\author{
Yucel Kadioglu*, Murat Ozturk \\ Department of Analytical Chemistry, Faculty of Pharmacy, Ataturk University, Turkey
}

\begin{abstract}
A rapid and sensitive spectrofluorimetric method was developed for the determination of amlodipine (AD), a calcium channel blocker, in the plasma. The type of solvent, the wavelength range, and the range of $\mathrm{AD}$ concentration were selected to optimize the experimental conditions. The calibration curves were linear $\left(\mathrm{r}^{2} \geq 0.997\right)$ in the concentration range of $0.1-12.5 \mathrm{ppm}$ of $\mathrm{AD}$. The limit of quantitation and limit of detection values for the method for plasma samples were $0.1 \mathrm{ppm}$ and $0.07 \mathrm{ppm}$, respectively. The precision calculated as the relative standard deviation was less than $3.5 \%$, and the accuracy (relative error) was better than $5.5 \%(n=6)$. The method developed in this study can be directly and easily applied for the determination of $\mathrm{AD}$ in the plasma without derivatization in plasma.
\end{abstract}

Uniterms: Amlodipine/determination. Spectrofluorimetric method/validation. Human plasma.

\begin{abstract}
Método espectrofluorometrico rápido e sensível é descrito para a determinação de anlodipina (AD), um bloqueador de canais de cálcio, em amostras de plasma. O tipo de solvente, a faixa de comprimento de onda e a faixa de concentração foram escolhidas a fim de otimizar as condições experimentais. As curvas de calibração foram lineares $(r \geq 0,997)$ na faixa de concentração de $0,1-12,5$ ppm de AD. Os valores LoQ e LoD do método para amostras de plasma foram $0,1 \mathrm{ppm}$ e $0,07 \mathrm{ppm}$, respectivamente. A precisão calculada como desvio padrão relativo (RSD) foi menor do que $3,5 \%$ e a precisão (erro relativo) foi melhor do que 5,5\% $(n=6)$. O método desenvolvido neste estudo pode ser fácil e diretamente aplicado para a determinação de $\mathrm{AD}$ sem derivatização no plasma.
\end{abstract}

Unitermos: Anlodipina/determinação. Método espectrofluorimétrico/validação. Plasma humano.

\section{INTRODUCTION}

Amlodipine (AD), 2-[(2-aminoethoxy)methyl]-4-(2-chlorophenyl)-3-ethoxycarbonyl-5-methoxycarbonyl-6-methyl-1,4-dihydropyridine (Figure 1), is a dihydropyridine calcium channel blocker, which is used for the treatment of hypertension and angina (Reynolds, 1996; European Pharmacopoeia, 2001; Civantos, Aleixandre, 2004). In addition, AD may be used for dilated cardiomyopathy, and AD has ameliorating effects on the plasma and myocardial catecholamines levels and significantly reduces calcium deposition (Resnick, Laragh, 1985; Khattar et al., 1999).

Several analytical procedures are available for the

"Correspondence: Y. Kadioglu. Department of Analytical Chemistry, Faculty of Pharmacy, Ataturk University, 25240 - Erzurum, Turkey. E-mail: yuce1@atauni.edu.tr; yucelkadi@yahoo.com<smiles>CCOC(=O)C1=C(COCCN)NC(C)=C(C(=O)OC)C1c1ccccc1Cl</smiles>

FIGURE 1- Structural formula of AD.

analysis of $\mathrm{AD}$ in the plasma/serum, such as high-performance liquid chromatography (HPLC) with fluorescence detection (Tatar, Atamaca, 2001; Bahrami, Mirzaeei, 2004); ultraviolet (UV) detection (Yeung et al., 1991; Coseberg, Carson, 1997; Patel et al., 1998; Johansen, Genner, 2003; Zarghi et al., 2005); amperometric detection (Shirmooka et al., 1989; Josefsson et al., 1995); highperformance thin layer chromatography method (Pandya 
et al., 1995); liquid chromatography tandem mass spectrometry (LC-MS-MS) method (Yasud et al., 1996; Chen et al., 2001; Massaroti et al., 2005; Nirogi et al., 2006; Ma et al., 2007; Sirikatitham et al., 2008); gas chromatography (GC) method (Bresford et al., 1987; Scharpf et al., 1994; Monkman et al., 1996); GC-MS method (Feng et al., 1998) and electrochemical analysis (Gazy, 2004). Generally, AD in the plasma has been analyzed by HPLC (-MS) and GC methods. These methods have the required sensitivity and selectivity for the analysis of AD in biological fluids. However the sophisticated instrumentation and high cost of analysis involved in these methods have limited their use in the laboratories for the analysis of AD in its biological samples. Moreover, these instruments are not available in most laboratories, particularly in third world countries. Typically, spectrofluorimetry is one of the most convenient analytical techniques, because of its inherent simplicity, low cost, and wide availability of the instrument in most laboratories (Frei, Lawrence, 1981; Knap, 1979; Belal et al., 2008; Shaalan, Belal, 2010). However, many of the analytical methods reported in the literature have limitations because these methods require derivatization of AD using different substances. These methods have disadvantages such as poor selectivity, heating, or an extraction step and are expensive and time-consuming (Frei, Lawrence, 1981; Abdel-Wadood et al., 2008; Belal et al., 2008; Shaalan, Belal, 2010). A literature survey indicated 3 spectrofluorimetric methods for the analysis of $\mathrm{AD}$ in pure and pharmaceutical dosage forms. The first method was based on a condensation reaction with ninhydrin and phenylacetaldehyde in a neutral buffered medium, and the second method was based on a reaction with 7-chloro-4-nitro-2,1,3-benzoxadiazole (NBD-Cl) reagent in a slightly basic buffered medium (Abdel-Wadood et al., 2008); further, Shaalan and Belal (2010) examined simultaneous spectrofluorimetric determination of $\mathrm{AD}$ besylate and valsartan in tablets containing a combination of the drugs. In addition, the binding of aspirin and $\mathrm{AD}$ to human serum albumin in an aqueous solution at $\mathrm{pH} 7.4$ has been examined using multiple techniques (fluorescence quenching, resonance light scattering, three-dimensional fluorescence spectroscopy, Fourier transform-infrared [FT-IR] spectroscopy, and zeta-potential measurements) (Abdollahpour et al., 2011). Literature review indicates that to date no studies have reported concerning the spectrofluorimetric determination of $\mathrm{AD}$ in the plasma. This encouraged us to study the native fluorescence of the drug in an attempt to develop a simple and sensitive spectrofluorimetric method for determination of the drug without derivatization, either alone or in its co-formulated preparations with a simple sample preparation. The method was extended to the in vitro determination of the drug in spiked human samples, and we obtained promising results.

\section{MATERIAL AND METHODS}

\section{Apparatus}

The fluorescence spectra and measurements were recorded using a Perkin Elmer LS 45 fluorescence spectrometer equipped with FL WinLab software, and a 150 W xenon arc lamp: the excitation $\left(\lambda_{\text {exc }}\right)$ and emission $\left(\lambda_{\text {em }}\right)$ wavelengths were $360 \mathrm{~nm}$ and $440 \mathrm{~nm}$, respectively. Measurements were performed using a $10-\mathrm{mm}$ quartz cell. Slit width for both monochromators was set at $10 \mathrm{~nm}$.

\section{Reagents}

AD used as a reference substance (purity 99.2\%) was purchased from Novartis Pharmaceutical Industry (Ankara, Turkey). All analytical chemicals were purchased from Merck (Germany). Drug-free blank plasma was obtained from 3 hospitals in Erzurum, Turkey.

\section{Preparation of calibration standards and quality control samples}

The standard stock solution of AD (100 ppm) was prepared by dissolving an appropriate amount of AD in ethanol. The stock solution was subsequently diluted in the same diluents to obtain working standard solutions (WS) at 8 concentrations level. All solutions were stored at $-4{ }^{\circ} \mathrm{C}$.

A suitable amount of the WS of AD was added to 0.2 $\mathrm{mL}$ of the drug free human plasma to yield final respective concentrations of $0.1,1,2,4,6,8,10$ and 12.5 ppm of AD in the plasma. Quality control (QC) samples $(1.5,4.5$, and $7.5 \mathrm{ppm}$ ) were also prepared in a similar manner.

\section{Sample preparation procedure}

The plasma samples were stored at $-20{ }^{\circ} \mathrm{C}$ and allowed to thaw at room temperature before processing. An appropriate amount of standard solutions of AD were spiked into $0.2 \mathrm{~mL}$ of each concentration of drug-free human plasma and mixed. Then, $1.0 \mathrm{~mL}$ buffer solution $\left(1 \mathrm{M}\right.$ sodium carbonate $\left[\mathrm{Na}_{2} \mathrm{CO}_{3}\right] / 4 \mathrm{M}$ sodium bicarbonate $\left[\mathrm{NaHCO}_{3}\right], \mathrm{v} / \mathrm{v}$ ) and $3 \mathrm{~mL}$ of extraction solvent (ether:hexane $1: 1 \mathrm{v} / \mathrm{v}$ ) were added, and the solution was vortexed for about $10 \mathrm{~min}$. The mixture was centrifuged for $10 \mathrm{~min}$ at $4000 \times \mathrm{g}$. The supernatant was transferred to the evaporation tube and evaporated to dryness in a thermostatically controlled water-bath maintained at $30^{\circ} \mathrm{C}$ 
under the stream of nitrogen for $20 \mathrm{~min}$. The residue was dissolved in $3 \mathrm{~mL}$ of ethanol and transferred to quartz cells for analysis. Blank solution was prepared in a similar manner using drug-free human plasma.

\section{Method validation}

To ensure optimization of the method in light of the standardization rules, we developed this method along with the process of validation. The assay method was evaluated through determination of linearity, precision, specificity, limit of detection, limit of quantification, accuracy and recovery, and the relative matrix effect was investigated by analyzing the different human plasma samples (Green, 1996; ICH, 1996).

\section{Data analysis}

All statistical calculations were performed using the Statistical Product and Service Solutions (SPSS) for Windows, version 10.0. Correlations were considered statistically significant if calculated $\mathrm{P}$ values were $\leq 0.05$.

\section{RESULTS AND DISCUSSION}

\section{Development of extraction procedure}

To reduce the endogenous interfering substances, protein precipitation was performed. In the present method, the buffer solution $\left(\mathrm{Na}_{2} \mathrm{CO}_{3} / \mathrm{NaHCO}_{3}\right)$ was used as the precipitant, and the ratio of the buffer solution to plasma was examined. The results showed that the best protein precipitation was achieved at a ratio of 1:4. Ether:hexane $(1: 1 \mathrm{v} / \mathrm{v})$ was used as the solution for extraction after reconstitution of the residue, and the solution showed a good performance.

No internal standard was used in our study. An internal standard, although desirable, is not essential in the method as described. Because, external standards could be prepared along with the unknown samples and subsequently treated in parallel with the latter, an internal standard may not be required. In the present study, the external standard showed a satisfactory correlation and thus an internal standard was not required.

\section{Optimization of parameters}

The fluorescence spectra (excitation and emission) obtained for AD solutions extracted from spiked plasma reveals that the maximum $\lambda_{\mathrm{exc}}$ and $\lambda_{\mathrm{em}}$ show a band peak at $360 \mathrm{~nm}$ and $440 \mathrm{~nm}$, respectively (Figure 2).

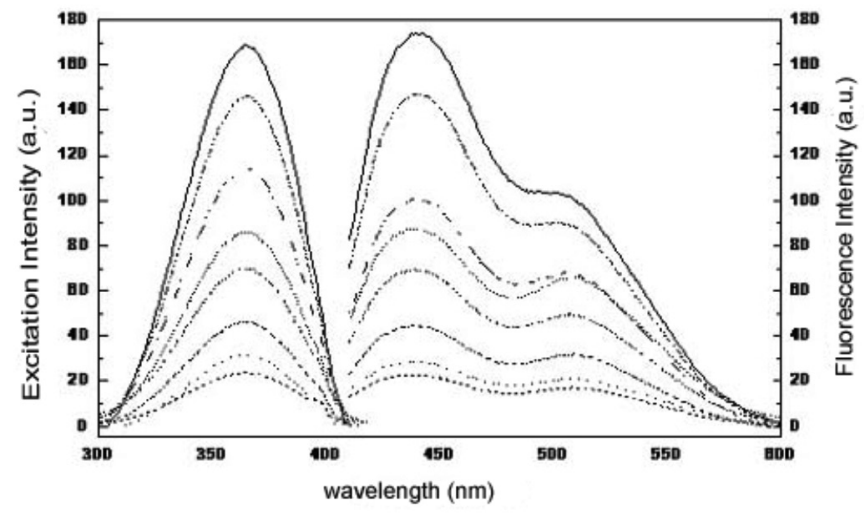

FIGURE 2 - Fluorescence spectra of AD solutions extracted from spiked human plasma $(0.1,1,2,4,6,8,10$ and $12.5 \mathrm{ppm})$.

We evaluated the influence of the solvent on the relative intensity of fluorescence of AD. A solvent is an important parameter for developing an analytical method using fluorescence because the signal may undergo modifications according to the solvent used. Changing solvent polarity can alter the absorption and emission spectra of AD. Solvents evaluated were ethanol, methanol, acetonitrile, ether and water and the maximum fluorescence intensity was obtained in ethanol, and thus it was used throughout the study.

\section{Linearity and calibration curve}

Linearity of a calibration function is a critical analytical parameter (Green, 1996; ICH, 1996). The correlation coefficient $r^{2}$ has often been used to determine linearity. However, a correlation coefficient close to unity does not necessarily indicate a linear calibration function. Therefore, statistical tests for significant lack of fit to a linear model were used in these calibration experiments.

Solutions for the calibration curve were prepared by diluting the standard stock solutions (100 ppm) with ethanol in the range $0.09-13 \mathrm{ppm}$. These solutions were spiked in the plasma and then extracted from the plasma. Then, for each concentration, the emission fluorescence at $440 \mathrm{~nm}$ (excited at $360 \mathrm{~nm}$ ) was measured 6 times in a random order. We found that the standard deviation of each measurement differs for each solution and therefore heteroscedasticity was present. In this case, the intercept A and slope B were estimated by weighted regression, which minimizes the value of $\Sigma_{\mathrm{ij}} w_{\mathrm{i}}\left(R_{i j}-\check{R}_{I}\right)^{2}$ where $R_{i j}$ is the experimental fluorescence intensity value for each $c_{i j}$, $\check{\mathrm{R}}_{I}$ is the fitted intensity, $\left(R_{i j}-\check{R}_{I}\right)$ is the difference between experimental and fitted values or residuals. The weight is given by $w i=\sigma i-2$, where $\sigma i$ is the standard deviation of the fluorescence intensity at the concentration $c_{i}$. 
The linear calibration range of solutions extracted was $0.1-12.5 \mathrm{ppm}$ in ethanol. The equation for the calibration curve is $\mathrm{I}=\mathrm{A}+\mathrm{B} \times \mathrm{C}$, where $\mathrm{I}$ is the fluorescence intensity (in arbitrary units) and $\mathrm{C}$ is the concentration of $\mathrm{AD}$ in ppm, $\mathrm{A}$ is the intercept and B is the slope. After a weighted least squares linear fit of the fluorescence emission data, the following values were obtained: $\mathrm{A}=0.5418$, $\mathrm{B}=0.0524$, and $\mathrm{r}^{2}=0.9977$. The number of measurements (n) was 6 .

\section{Limit of detection and limit of quantification}

The limit of detection (LoD) and the limit of quantitation (LoQ) were determined by an empirical method in which a series of solutions containing decreasing amounts of AD were analyzed. LoQ is the lowest amount of analyte that can be quantitatively determined with a suitable precision $(\mathrm{RSD}<10 \%)$ and accuracy $(80-120 \%)$. LoD is the lowest amount of analyte in a sample that can be detected but not necessarily quantitated as an exact value (RSD $<$ $10 \%)(\mathrm{ICH}, 1996)$. LoQ and LoD values of the proposed method were $0.1 \mathrm{ppm}$ and $0.07 \mathrm{ppm}$, respectively.

\section{Accuracy and precision}

The precision of the analytical method was determined by repeatability (within-day) and intermediate precision (between-day). Repeatability was evaluated by analyzing spiked blank human plasma samples 6 times per day at the same concentrations, which were plasma QC samples $(1.5,4.5$, and $7.5 \mathrm{ppm})$ and during the same day. The intermediate precision was evaluated by assaying the same plasma samples in 6 times once daily for 6 days. The precision of the method was expressed as the relative standard deviation $(\mathrm{RSD} \%=100 \mathrm{x}$ standard deviation/mean) and the accuracy of method was expressed as the percent of mean deviation from known concentration [relative error $(\mathrm{RE} \%)=($ concentration found - known concentration $) x$ 100/known concentration]. The RSD\% values for withinday and between-day precision were $\leq 3.5 \%$. The RE $\%$ for within-day and between-day accuracy of proposed method were $\leq 5.5 \%$. Precision and accuracy studies in human plasma showed acceptable RSD\% and RE\% values. The results are shown in Table I.

\section{Extraction recovery}

The extraction recovery of $\mathrm{AD}$ from human plasma was determined at 1, 2, 6, 8, 10 and 12 ppm concentrations by comparing the data obtained by the direct injection of standard aqueous solutions with those obtained after the entire extraction procedure. The extraction recoveries of $\mathrm{AD}$ from plasma were between $90.0 \%$ and $99.7 \%$, as shown in Table II.

TABLE I - Accuracy and precision of proposed method

\begin{tabular}{lcccccc}
\hline Added $(\mathrm{ppm})$ & \multicolumn{3}{c}{ Within-day } & \multicolumn{3}{c}{ Between-day } \\
\cline { 2 - 7 } & $\begin{array}{c}\text { Found } \pm \mathrm{SD}^{\mathrm{a}} \\
(\mathrm{ppm})\end{array}$ & $\begin{array}{c}\text { Accuracy } \\
{ }^{\mathrm{b}} \mathrm{RE} \%\end{array}$ & $\begin{array}{c}\text { Precision } \\
{ }^{c} \mathrm{RSD} \%\end{array}$ & $\begin{array}{c}\text { Found } \pm \mathrm{SD}^{\mathrm{a}} \\
(\mathrm{ppm})\end{array}$ & $\begin{array}{c}\text { Accuracy } \\
{ }^{\mathrm{b}} \mathrm{RE} \%\end{array}$ & $\begin{array}{c}\text { Precision } \\
{ }^{\text {} R S D} \%\end{array}$ \\
\hline 1.5 & $1.43 \pm 0.08$ & -4.6 & 3.5 & $1.52 \pm 0.07$ & 1.0 & 3.0 \\
4.5 & $4.68 \pm 0.06$ & -3.9 & 1.1 & $4.75 \pm 0.09$ & 5.5 & 1.6 \\
7.5 & $7.26 \pm 0.07$ & -3.6 & 0.8 & $7.24 \pm 0.09$ & -3.5 & 1.0 \\
\hline
\end{tabular}

a SD: standard deviation of six replicate determinations; ${ }^{\mathrm{b}} \mathrm{RE}$ : relative error; ${ }^{\mathrm{R}} \mathrm{RSD}$ : relative standard deviation.

TABLE II- Extracted recovery of AD in spiked human plasma $(\mathrm{n}=6)$

\begin{tabular}{ccccc}
\hline Added $(\mathrm{ppm})$ & Found $(\mathrm{ppm})$ & Recovery $(\%)$ & Mean \pm SD & RSD $(\%)$ \\
\hline 1.0 & 0.90 & 90.0 & & \\
2.0 & 1.89 & 94.5 & & \\
6.0 & 5.54 & 92.3 & $94.42 \pm 3.67$ & \\
8.0 & 7.98 & 99.7 & \\
10.0 & 9.23 & 92.3 & \\
12.0 & 11.72 & 97.7 & \\
\hline
\end{tabular}




\section{Stability of plasma samples}

To determine of the stability of $\mathrm{AD}$ in the plasma, standard solutions of low (1.5 ppm), medium (5.0 ppm), and high (11.5 ppm) concentrations of the spiked calibration standards in the plasma were stored at room temperature, in a refrigerator $\left(4^{\circ} \mathrm{C}\right)$ and in a deep freezer $(-20$ ${ }^{\circ} \mathrm{C}$ ) for 1 week. One set of spiked samples was assayed immediately and considered as the standard (100\%). The results were evaluated, and these measurements were compared with those of standards and expressed as percentage deviation. AD was found to be stable for $24 \mathrm{~h}$ at room temperature and in the refrigerator and for at least 1 week in the deep freezer.

For freeze-thaw stability studies, $1.5,5.0$, and 11.5 ppm concentrations of AD were spiked into the plasma, and these samples were frozen at $-70{ }^{\circ} \mathrm{C}$ for 1 week and thawed 3 times a day. After these assays, the samples were extracted and analyzed. Our results showed that samples were stable for $24 \mathrm{~h}$. In addition, we examined the stability of the analyte stock solution during 2 weeks in the same assay. Our results indicated that the stock solution was stable during 2 weeks at refrigerator temperature.

\section{Matrix effect}

For examined of the relative matrix effect, different human plasma samples were obtained from 3 hospitals in Erzurum, Turkey. Each blank sample was tested using the proposed extraction procedure for interference. The matrix effect was investigated using the following procedure: the fluorescence intensity of the standard QC samples was compared to the fluorescence intensity of AD in spiked QC sample with 3 different plasma samples. During the preparation of QC samples at same concentration level, each plasma sample was used only once. Matrix effect was calculated using this formula: $I_{1} / I_{2}$ x 100; where $I_{1}$ is the fluorescence intensity of the spiked QC samples in the plasma and $\mathrm{I}_{2}$ is the equivalent concentration of the standard samples in ethanol. Results of the matrix effect are summarized in Table III.

TABLE III - Results of matrix effect for AD in plasma

\begin{tabular}{lccc}
\hline \multirow{2}{*}{ Added (ppm) } & 1. Plasma & 2. Plasma & 3. Plasma \\
\cline { 2 - 4 } & ME (RSD), \% & ME (RSD), \% & ME (RSD), \% \\
\hline 1.5 & $98.3(3.7)$ & $97.9(4.8)$ & $94.8(5.2)$ \\
4.5 & $96.0(4.5)$ & $98.3(2.5)$ & $97.9(6.4)$ \\
7.5 & $97.8(3.6)$ & $96.9(4.4)$ & $95.6(5.6)$ \\
\hline
\end{tabular}

ME: matrix effect, RSD: relative standard deviation

\section{CONCLUSIONS}

We developed and successfully validated the spectrofluorimetric method for the quantitative analysis of $\mathrm{AD}$ in human plasma. The proposed method is a rapid, simple, accurate, and reproducible method for the quantitative analysis of AD in human plasma. The proposed method is convenient for routine determination of AD in the plasma and quality control laboratories that require an economic and rapid method.

\section{ACKNOWLEDGEMENTS}

The authors are grateful to Ataturk University for the financial support of this work.

\section{REFERENCES}

ABDEL-WADOOD, H.M.; MOHAMMED, N.A.; MAHMOUD, A.M. Validated spectrofluorometric methods for determination of amlodipine besylate in tablets. Spectrochim. Acta., v.70, part A, p.564-570, 2008.

ABDOLLAHPOUR, N.; ASSODEH, A.; SABERI, M.R.; CHAMANI, J. Separate and simultaneous binding effects of aspirin and amlodipine to human serum albumin based on fluorescence spectroscopic and molecular modeling characterizations: A mechanistic insight for determining usage drugs doses. J. Lumin., v.131, p.1885-1899, 2011.

BAHRAMI, G.; MIRZAEEI, S. Simple and rapid HPLC method for determination of amlodipine in human serum with fluorescence detection and its use in pharmacokinetic studies. J. Pharm. Biomed. Anal., v.36, p.163-168, 2004.

BELAL, S.F.; HAGGAG, R.S.; SHAALAN, R.A-A. The use of an aromatic substitution reaction in the spectrophotometric determination of selected amino or thiol containing drugs. J. Food Drug Anal., v.16, p.26-33, 2008.

BRESFORD, A.P.; MARCRAC, P.V.; STOPHER, D.A.; WOOD, B.A. Analysis of amlodipine in human plasma by gas chromatography. J. Chromatogr., v.420, p.178-183, 1987.

CHEN, X.Y.; LUAN, Y.; ZHONG, D.F.; DU, Z.M. Determination of amlodipine in human plasma by liquid chromatographytandem mass spectrometry. Yао Хие Хие Ваo, v.36, p.51-54, 2001. 
CIVANTOS, B.; ALEIXANDRE, A. Blood pressure and a-vascular reactivity in hypertensive rats treated with amlodipine and dietary Ca. Eur. J. Pharmacol., v.489, p.101-110, 2004.

COSEBERG, S.H.; CARSON, D.J.L. A fatal case of amlodipine poisoning. J. Anal. Toxicol., v.21, p.221-223, 1997.

EUROPEAN PHARMACOPOEIA. 3.ed. Strasbourg: Council of Europe, 2001. p.431-432.

FENG, Y.; MENG, Q.; GUO, X.; YANG, D.; HE, Y. Human plasma amlodipine GC-MS determination. Guang. Yaox. Xue., v.14, p.118-121, 1998.

FREI, R.W.; LAWRENCE, J.F. (Eds.). Chemical derivatization in analytical chemistry. New York: Plenum Press, 1981. v.1, chap.4, p.210-221.

GAZY, A.A.K. Determination of Amlodipine besylate by adsoptive square-wave anodic stripping voltammetry on glassy carbon electrode in tablets and biological fluids. Talanta, v.62, p.575-582, 2004.

GREEN, J.M. A practical guide to analytical method validation. Anal. Chem. News Feat., v.1, p.305-309, 1996.

INTERNATIONAL CONFERENCE ON HARMONISATION. ICH. Topic Q2B, Validation of Analytical Procedures: Methodology, Proceedings of the Commission of the European Communities. Rockville, 1996. p.1-10.

JOHANSEN, S.S.; GENNER, J. A fatal case of amlodipine poisoning. J. Clin. Forensic Med., v.10, p.169-172, 2003.

JOSEFSSON, M.; ZACKRISSON, A.L.; NORLANDER, B. Sensitive high performance liquid chromatographic analysis of amlodipine in human plasma with amperometric detection and a single step solid phase sample preparation. J. Chromatogr. B., v.672, p.310-317, 1995.

KNAPP, D.R. Handbook of analytical derivatization reactions. New York: Wiley, 1979. p.621-669.

KHATTAR, R.S.; SENIOR, R.; SWALES, J.D.; LAHIRI, A. Value of ambulatory intra-arterial blood pressure monitoring in the long-term prediction of left ventricular hypertrophy and carotid atherosclerosis in essential hypertension. $J$. Hum. Hypertens., v.3, p.111-116, 1999.
MA, Y.; QIN, F.; SUN, X.; LU, X.; LI, F. Determination and pharmacokinetic study of amlodipine in human plasma by ultra performance liquid chromatography-electrospray ionization mass spectrometry. J. Pharm. Biomed. Anal., v.43, p.1540-1545, 2007

MASSAROTI, P.; MORAES, L.A.B.; MARCHIRETTO, M.A.M.; CASSIANO, N.M.; BERNASCONI, G.; CALAFATTI, S.A.; BARROS, F.A.P.; MEURER, E.C.; PEDRAZZOLI, J. Development and validation of a selective and robust LC-MS/MS method for quantifying amlodipine in human plasma. Anal. Bioanal. Chem., v.382, p.1049-1054, 2005.

MONKMAN, S.C.; ELLIS, J.S.; CHOLERTON, S.; THOMASON, J.M.; SEYMOUR, R.A.; IDLE, J.R. Automated gas chromatographic assay for amlodipine in plasma and gingival cevicular fluid. J. Chromatogr. B., v.678, p.360-364, 1996.

NIROGI, R.V.; KANDIKERE, V.N.; MUDIGONDA, K.; SHUKLA, M.; MAURYA, S. Sensitive and rapid liquid chromatography/tandem mass spectrometry assay for quantification of amlodipine in human plasma. Biomed. Chromatogr., v.20, p.833-842, 2006.

PANDYA, K.K.; SATIA, M., GANDHI, T.P.; MODI, I.A.; MODI, R.I., CHAKARVARTHY, B.K. Detection and determination of total amlodipine by high performance thin layer chromatography: a useful technique for pharmacokinetic studies. J. Chromatogr. B., v.667, p.315$320,1995$.

PATEL, Y.P.; PATIL, S.; BHOIR, I.C.; SUNDARESAN, M. Isocratic, simulataneous reversed-phase high-performance liquid chromatographic estimation of six drugs for combined hypertension therapy. J. Chromatogr. A., v.828, p.283-286, 1998.

RESNICK, L.M.; LARAGH, J.H. Renin, calcium and the pathophysiologic basis of antihypertensive theraphy. Am. J. Cardiol., v.56, p.68-74, 1985.

REYNOLDS, J.E.F. (Ed.) Martindale-The Extra Pharmacopoeia. 31.ed. London: The Royal Pharmaceutical Society, 1996. p.819-820.

SCHARPF, F., RIEDEL, K.D.; LAUFEN, H.; LEITOLD, M. Enantioselective gas chromatographic assay with electroncapture detection for amlodipine in biological samples. $J$. Chromatogr. B., v.655, p.225-233, 1994. 
SHAALAN, R.A.; BELAL, T.S. Simultaneous spectrofluorimetric determination of amlodipine besylate and valsartan in their combined tablets. Drug Test. Anal., v.2, p.489-493, 2010.

SHIRMOOKA, K.; SAWADA, Y.; TATEMATSU, H. Analysis of amlodipine in serum by sensitive high performance liquid chromatographic method with amperometric detection. $J$. Pharm. Biomed. Anal., v.7, p.1267-1272, 1989.

SIRIKATITHAM, A.; PANRAT, K.; TANMANEE, N. Determination of amlodipine in human plasma by electrospray ionization LC-MS/MS method: validation and its stability studies. Song. J. Sci. Technol., v.3, p.455-462, 2008.

TATAR, S.; ATAMACA, S. Determination of amlodipine in human plasma by high-performance liquid chromatography with fluorescence detection. J. Chromatogr. B., v.758, p.305-310, 2001.
YASUD, T.; TANAKA, M.; IBA, K. Quantitative determination of amlodipine in serum by liquid chromatography with atmospheric pressure chemical ionization tandem mass spectrometry. J. Mass Spectrom., v.31, p.879-884, 1996.

YEUNG, P.K.F.; MOSHER, S.J.; POLLAK, P.T. Liquid chromatography assay for amlodipine. Chemical stability and pharmacokinetics in rabbits. J. Pharm. Biomed. Anal., v.9, p.565-571, 1991.

ZARGHI, A.; FOROUTON, S.M.; SHAFAATI, A.; KHODDAM, A. Validated HPLC method for determination of amlodipine in human plasma and its application to pharmacokinetic studies. Farmaco, v.60, p.789-792, 2005.

Received for publication on $25^{\text {th }}$ November 2011 Accepted for publication on $21^{\text {st }}$ August 2012 